\title{
Research on the Integration of College Sports and Social Sports from the Perspective of Lifelong Sports*
}

\author{
Ronghua Zhang \\ Hubei Business College \\ Wuhan, China 430079
}

\begin{abstract}
This article takes the "lifelong sports" thinking as the guidance, and takes the physical education curriculum reform of Hubei Business College as a typical case. Through the combination of qualitative and quantitative methods such as literature, interviews, questionnaires and mathematical statistics, it analyzed and studied the background of the integration of college sports and social sports and the existing problems, and also proposed suggestions and countermeasures. It has certain practical and guiding significance for promoting lifelong physical education and social sports development in colleges and universities.
\end{abstract}

Keywords-lifelong sports; college sports; social sports; integration

\section{INTRODUCTION}

At present, China is making great efforts to transform from a large sports country to a sports power. The participation of the whole people in physical exercise is one of the symbols of a sports power. College students enter the society after graduation. So the combination of college sports and social sports and the cultivation of college students' lifelong sports awareness are conducive to the development of social sports and the implementation of comprehensive fitness programs. It will gradually make China a real sports power.

\section{RESUltS AND ANALYSIS}

\section{A. Explication of Concept}

1) Social sports: Social sports are also called "mass sports" or "public sports". It is the physical exercises that people outside the school do for fitness, mental health, vigor, amusement, health care and so on. Its performance is rich in content and diverse in form. The fundamental task of social sports is to strengthen the people's physical fitness and improve the quality of the people. The development of social sports is one of the signs of civilization, health and

*Project: Humanities and social science research project of Hubei Provincial Department of Education

Project name and number: Research on the integration of college sports and social sports from the perspective of lifelong sports — taking the sports course reform in Hubei Business College as an example (18G139) science of modern society. There are there functions of social sports: the essential function is to enhance the physical and mental health and to strengthen physical fitness; the cultural function is to make positive effect on people's views, moralities, behaviors, habits and so on; the economic function is to increase the adaptive capacity for workers in work, reduce occupational disease and promote the development of sports industry.

2) College sports: School physical education refers to the physical activities of students participating in the school. By cultivating students' sports interests, attitudes, habits, knowledge and abilities, students' physical quality is enhanced, good morality and will quality are cultivated, and students' physical and mental health is promoted. College sports belongs to school physical education. It is the sports activities doing in colleges and universities.

\section{B. The Inevitability of the Integration Between the \\ Development of College Sports and Social Sports}

In order to build China into a sports power, on October 20, 2014, the State Council issued the "Several Opinions on Accelerating the Development of Sports Industry to Promote Sports Consumption", which raised the implementation of national fitness to the national strategic level and greatly promoted the development of Chinese social sports. However, it should be noted that Chinese social economy is still in developing. With very little funding, serious shortage of sports facilities and equipment, and the extreme lack of social sports instructors, the development of social sports is restricted seriously. College sports play an indispensable role in promoting the healthy development of social sports. First, college sports are the last stage of school education, which plays an important role on cultivating the students' sports habits and lifelong sports awareness. Second, college physical education teachers have the advantages of a large number, high quality, fine business, and no need to take classes. If some college physical education teachers are used to guide the development of social sports, it will be able to make up for the shortage of social sports instructors. Finally, from the perspective of many scholars at home and abroad, it is feasible to open school sports venues to the society. The advantages outweigh the disadvantages. It will provide necessary material conditions for social sports development. 


\section{The Current Problems in College Physical Education Curriculum}

Taking the current situation of the physical education curriculum of Hubei Business College as an example, although a series of reforms have been carried out on the physical education curriculum, for example, boys and girls are separated from classes, and optional courses are taught, which further improves the physical education curriculum, there are still deviations and lags in the guiding ideology of physical education curriculum and lifelong sports thinking.

1) The disconnection of college sports, lifelong sports and social sports: The survey shows that most colleges only offer physical education courses in the first and second grades. Most students do not participate in physical exercise in the third and fourth grades. Students' physical exercise habits and abilities can't be maintained during school, let alone cultivate students' lifelong sports awareness.

2) The problem of setting up the content of college physical education curriculum: Most of the physical education curriculum content in colleges and universities follows traditional sports and athletics projects, such as the three major balls and track and field events. These projects are repeated with the secondary school project, and the second is boring, causing students to lose interest in physical education classes even being disgusted with physical education. Physical education classes in colleges and universities should open projects that can attract students' interest, especially those that can be integrated with social sports, which is conducive to the development of students' lifelong sports habits.

3) The attention to classroom teaching and the neglect of extracurricular exercises: Physical education teachers often feel that students have mastered the learning content in a certain class. But when it comes to next lesson to teach, it seems that the knowledge of the students has been returned to the teacher. Especially in the final assessment, the expected teaching effect is usually failed to achieve. The point is that students only pay attention to classroom learning, while ignoring extracurricular active practice. It is not conducive for students to cultivate the habits and abilities to exercise for life.

\section{Countermeasures and Suggestions - Implementation of Club-system Physical Education Internal and External Integration}

In the developed countries such as the United States and Germany, college sports activities generally adopt the form of clubs. Physical education is as important as extracurricular sports, which is in line with their idea of "cultivating students for lifelong sports." At present, it is difficult for colleges and universities in China which only focus on physical education to adapt to the development in the new situation. Therefore, the reform of physical education in colleges and universities is imperative. It is necessary to reset the physical education curriculum and build an internal and external integrated model of club-system physical education.
1) Implementing the guiding ideology of club-system physical education internal and external integration: Focus on the sports teaching in club system, to make the inside and outside of the class integrate. Encourage students to participate in sports activities, learn sports knowledge in sports practice, improving sports skills, experience the fun of sports, cultivate self-exercise ability, and develop exercise habits, so that we can lay a good foundation for lifelong sports.

2) Establishing the thought of health-priority lifelong sports: The "Resolution of the Central Committee of the Communist Party of China and the State Council on Deepening Educational Reform and Promoting Quality Education in an All-round Way" states: "School education should establish the guiding ideology of health priority, strengthen physical education, and enable students to master basic sports skills and develop good habits of exercising." The integration of inside and outside of the club-based physical education curriculum reflects the guiding philosophy of health-priority life-long sports.

3) Developing self-sports awareness: College sports are in the transition from "educational sports" to "self-sports". College sports reform must be bold and innovative in terms of curriculum and teaching style in the spirit of fun, relaxation, freedom, and entertainment. Cultivate students' sports interest, and encourage students to actively participate in sports, master the technology of their favorite sports, and lay the foundation for lifelong physical exercise.

4) Implementing the teaching objectives of internal and external integrated club-system physical education classes: The teaching goal of the internal and external integrated club-system sports should include two aspects: sports skills and knowledge mastery, and attitudes and habit formation.

5) Implementing the operational management of clubsystem physical education internal and external integration: The club-system physical education internal and external integration has broken the traditional practice of physical education. It has integrated physical education, extracurricular sports activities, group competitions and sports team training into a comprehensive form of physical education.

a) Teaching operation of club-system physical education internal and external integration

- The principle of setting up various types of individual clubs: usually set up individual clubs such as ball, physical, art, entertainment, fighting, health care, etc.

- The selection principle of teaching materials: the breadth of teaching content should be broadened to help all students actively participate in sports learning and exercise, experience the fun of sports, and better meet the needs of individuals, groups and social development.

- The teaching options of club-system physical education internal and external integration: Students can choose any single club and class teacher of 
different levels and different projects according to the course information, their own needs and interests, regardless of the college, grade or class.

- The teaching form of club-system physical education internal and external integration: it should strive to achieve the combination of centralized guidance and differential treatment, and strengthen the cultivation of students' self-conscious training ability. The entire teaching method has been transformed from "teachercentered" to "student-independent".

- The teaching examination and evaluation of clubsystem physical education internal and external integration: According to the characteristics of each individual club, the mastered special techniques and physical health standards, as well as the attendance rate, competition results, participation in guidance, and organization of social sports, a relatively uniform evaluation standard should be formulated. Teachers can use the combination of results and process to do the examination and evaluation. In addition to the above assessments, each individual club teacher organizes different levels of testing in each specified period of the semester. Students who pass the test can obtain corresponding grade certificates (divided into national, provincial, and school level).

b) The management of internal and external integrated club-system physical education: Management is mainly student-oriented and teacher-supplemented.

c) The competition management of club-system physical education internal and external integration: The good management of the sports competition is the key to grasping the universities' leisure sports. It is generally based on a fixed season time and a competition project to form a convention. Usually the school-level large-scale competitions and comprehensive competitions are sponsored by the Ministry of Sports. The individual competitions are sponsored by the club. The college-level competitions and other types of competitions are jointly organized by the student unions or with the clubs.

6) The special advantages of the implement of internal and external integrated club-system physical education

a) Starting from the overall education, construct the integrated teaching inside and outside the club-system physical education: club-system physical education internal and external integration teaching has the following characteristics in establishing new college sports thoughts and concepts:

- Club-system physical education internal and external integration contains rich educational connotations. It breaks the original college sports management model and makes the college physical education have integrity and continuity.

- It links the physical education classroom with the extracurricular sports organically and fully exerted the educational role of the invisible curriculum of the school. b) Highlighting participation autonomy and build a relaxed sports learning environment: The temptation of the club-system physical education internal and external integration is that students can choose their teachers and classes freely.

c) The pattern of management openness and building a landscape of entertainment, socialization and individualization: The implement of club-system physical education internal and external integration breaks the pattern and fortress of traditional college sports, establishes a learning style that is compatible with modern society, expands the caliber of college sports learning, increases the flexibility of physical education curriculum, and increases the freedom of students' choice.

d) Method flexibility has been increased: Build a student-centered evaluation incentive mechanism.

e) The competition of teachers is enhanced, and the faculty is built from a new perspective: The implement of club-system physical education internal and external integration has the following characteristics for the construction of the teaching staff:

- Form a mechanism of courses' selection, teachers' selection, and teaching evaluation.

- The sources of teachers are diversified. The combination of full-time teachers and part-time teachers has excellent instructors from social sports clubs; in the future, physical education teachers in colleges and universities will face professional challenges.

- The role of the teachers is in transformation. College physical education teachers must not only become experts and authorities of a certain project, but also become organizers and instructors of social sports.

- It is conducive to teachers to update the knowledge structure and improve the teaching level. The clubsystem physical education internal and external integration encourages creative teachers to stand out and establish a competitive mechanism for teachers to choose their jobs. This measure fully mobilized the enthusiasm of the majority of teachers, and promoted the quality of teaching from the passive requirements of the past to the initiative.

f) Operational operation will activate new growth points of college sports: The charging problem of clubsystem physical education internal and external integration has always been a hot issue and sensitive issue in college sports.

The main sources of funding are: colleges and universities bear all the expenses; the sponsors will be responsible for the funds; the universities and sponsors will jointly bear the funds; the colleges and universities will allocate funds; self-generating income to solve the operating expenses. 


\section{CONCLUSION AND SUGGESTIONS}

College sports urgently need to be reformed in order to adapt to the development of modern social sports. First, we must update our concepts, establish a health-priority thought, and build a curriculum system with rich content and perfect structure.

The ideas that must be followed in the reform of college physical education curriculum are: emphasizing the health and effectiveness of sports; emphasizing self-exercise, developing physical exercise habits, and laying the foundation for lifelong physical exercise.

College sports are the final stage of school sports. It must take into account the systematic and long-term nature of social sports, actively integrate with social sports, and develop towards life, science and socialization.

The implement of club-system physical education internal and external integration teaching fully stimulates students' interest, ability and habits in sports and lays the foundation for lifelong sports and quality education. Clubsystem teaching should be transformed from simple sports technology and skill learning to improving the overall sports culture quality.

University leaders and competent authorities should give high priority to the creation of conditions for the teaching of internal and external integrated club-system physical education.

Strengthen the construction of teachers, improve the professional level and ability of teachers, and improve the structure of teachers. Establish a competitive mechanism, improve the reward system, and give affirmation and reward to creative teachers.

\section{REFERENCES}

[1] Jiang Ling, Research on the Application of Social Sports Theory and Practice in the Integration of College Sports and Social Sports[J]. China Sport Science, 2005 (in Chinese)

[2] Ji Chanzhong, Yao Zhenguang, On the Socialization Orientation of College Physical Education Reform[J]. Journal of Chengdu Sports University, 2005(3):98-101 (in Chinese)

[3] Feng Taohai, Analysis on the Operation Mode and Management of College Sports Clubs, Journal of Jilin Institute of Physical Education, 2003, (1): 19-20 (in Chinese)

[4] Jiang Ling et al.,Practical Research on the Implementation of Club System Internal and External Integration in Public Physical Education in Colleges and Universities, Journal of Wuhan Institute of Physical Education. 2004.11 (in Chinese)

[5] He Shujuan. Structural Analysis and Structure of the Sociological Function of Physical Education in Colleges and Universities, Journal of Xi'an Institute of Physical Education,2006(1):112-115 (in Chinese) 